\title{
Organizational Governance Maturity and Its Impact on Internal Audit Activity
}

\author{
Osasu Obaretin (PhD, ACA, ACTI) * Unuagbon Owaghianye Edogiawerie \\ Department of Accounting, Faculty of Management Sciences, University of Benin
}

\begin{abstract}
This paper examined organizational governance maturity and its impact on internal audit activities of public establishments in Edo state. To achieve this, the paper gathered relevant data from a primary source with the aid of duly administered questionnaire to audit staff of public enterprises in Benin city, Edo State. However, the ordinary least square statistical techniques were used to analyze the data gathered. From the analysis, the paper concluded that both management support and management perception had no significant impact on public enterprises in Benin City at 5 per cent level of significance. And based on the findings of the study, the paper recommended that there is a need for increased management support activity and enhance management perception of the working of the internal audit unit so as to enhance their operational efficiency.
\end{abstract}

Keywords: internal audit, management support, management perception and governance maturity DOI: $10.7176 / \mathrm{EJBM} / 11-5-01$

\section{Introduction}

Efficiency of the internal audit unit in any organization is a vital aspect of every successful establishment, while the internal auditor who is charged with the administration of this unit is responsible for the safekeeping of the assets and liabilities and other constructive services which will help improve the operational efficiency of the organization through the evaluation of the accounting system in place, internal control mechanism, corporate policies implementation and executing special investigation assigned by the management (Salihu, 2015). Internal audit has become an unavoidable control mechanism in both the public and private sectors (Cohen \& Sayag, 2010).

Ebrahim, Abdullah and Faudziah (2014) opine that internal audit department is very essential in every organization and it is seen as the pivotal factor in the application of accounting systems which in turn, helps in evaluating the work of the unit. The internal audit unit is considered as the pillar of the business accounting as it is the segment that checks all business processes. The efficiency of internal audit helps develop the firm because the financial reports reflect the internal audit department's quality and the extent of organizational governance maturity.

According to Ejoh and Ejom (2014), the endeavour of internal auditing is to advance authoritative ability and achievement through positive criticism.

Atu, Adeghe and Atu (2014) argue that the contemporary business scandals worldwide which bewildered the business domain involving Enron in the USA, Parmalat in Italy, Cadbury in Nigeria and other notable companies were premised on accounting failures and revealed out the necessity for abundant advancement in organizational corporate governance and accounting information efficiency which in turn provides analytical ruling and enhance information for control.

The term 'organizational governance' is the set of policies, processes, customs, laws, and institutions influencing the method a corporation (or company) is directed, managed or controlled (Khatab, Masood, Zaman, Saleem\& Saeed, 2011). To Ahsan (2015) organizational governance is all about the system or mechanism an entity utilized to defend the rights of investors. Organizational governance is all about managing an organization in a way that ensures shareholders and other stakeholders expectation are met (Magdi \& Nedareh, 2002). Organizational governance addresses the charge for corporate administrators to act in the best interest of the firm's stakeholders especially, smaller shareholders or investors, by guaranteeing that only accomplishments that ease the supply of optimum allotment and added favourable outcomes are considered at all times. This is possible by creating an organizational ambience which promotes the acknowledgement of codes of conduct, that accept accountability, transparency, fairness and ethical behaviour in all business endeavour of the firm (Duke and Kankpang, 2011).

\subsection{Statement of the Research Problem}

The need for studies on the relationship between organizational governance maturity and management internal audit activity is important in a country like Nigeria where organizations are striving to gain credibility among local and global investors.

The literature on how organizational governance maturity help to shape the level of internal audit activity is, as far as we know, are scarce in Nigeria despite the growing studies - mostly in developed countries - suggesting that corporate governance maturity and internal audit activities are interrelated. This significant constraint our awareness of how management support and perception on organizational efficiency of internal audit and how 
governance maturity might boost or impede the informational properties of internal audit activities.

Some of the earlier research works that examined various determinants of internal audit activity have looked at factors like management support; management's perception; competence of internal audit unit staff; organizational independence, approved internal auditing standards; and their correlation with the internal audit activity: Examples of such studies include - Deribe \& Regasa (2014) in the USA; Farouk \& Hassan (2014) in Russia; Ziaee (2015) in Canada; Shewamene (2014) in Kenya; and Usang \& Salim (2015) in Sweden. It is worthy to note that no such study was carried out with special reference to Nigeria environment. Hence, this research focuses on the corporate governance maturity and internal audit activities with special focus on management support and management's perception with reference to Nigeria public sector. Accordingly, it is the expected that this paper and its outcome will help contribute in filling this gap. To this end, the following research questions were raised to guide the study:

1. What is the association between management support and internal audit activity in corporate organizations?

2. What is the association between management perception and internal audit activity in corporate organizations?

\subsection{Objectives of the Study}

The broad objective of this study is to examine the effect of organizational governance maturity on internal audit functions in public establishment in Nigeria; however, the specific objectives are to:

1. examine the effect of management support on internal audit activity in,

2. investigate the effect of management perception on internal audit activity in Nigeria.

\section{2 .Literature Review and Hypothesis Development}

\subsection{The concept of Organizational Governance}

Organizational governance has been characterized by Onuorah and Imene (2016) as a component for overseeing, coordinating and regulating the exercises of the organization with the point of making an incentive for investors. Additionally, Ponduri, Sailaja and Begum (2014) define organizational governance as a "framework by which business partnerships are coordinated and controlled". The organizational governance structure determines the conveyance of authorities and responsibilities among various members in the organization, for example, the board, investors and stakeholders modalities. It explains the guidelines and techniques for making a decision. In this light, it presents the structure by which organizational objectives and goals are set and procedure for achieving those targets and performance evaluation.

Adigwe, Nwanna and John (2016) argued that "there exists a narrow approach to organizational governance, which views the subject as the mechanism through which shareholders are assured that managers will act in their interests".

Consequently, organizational governance is seen as the arrangement of structures, forms, traditions, approaches, laws, and methodology that define the manner in which owners' assets are managed or controlled in a partnership, with the end goal to ensure the interests of the owners. These structures, traditions, strategies, laws and systems decide the manner in which a partnership is being governed.

\subsection{The concept of Organizational Governance Maturity}

A review of the literature showed that organizational governance maturity refers to the degree to which an organization established adequate governance structures, systems and processes, and the degree to which the board, management and employees implement and adhere to these governance structures, systems and processes (Gramling \& Hermanson, 2006; Marks, 2007).

The following two examples explain the interpretation of the definition of organizational governance maturity (Gramling \& Hermanson, 2006; Marks, 2007; Wikinson \& Plant, 2012): if an organization has neither established any form of governance framework (structures, systems and processes), nor is only in the initial stages of establishing the framework, it would be a signal that the organization is not mature in the aspect of organizational governance; if on the other hand, an organization has a well-established and operational framework (structures, systems and processes) in place, which all stakeholders are aware of and which is truly rooted within the organization, this would be an indication of an organization that is mature in respect of organizational governance.

An essential factor not to lose sight of when attempting to decode what organizational governance maturity is all about, is if the firm actually implements and adheres to the activities recorded in the governance framework (structures, systems and processes), as this would be the decisive factor when assessing the maturity of the organization in respect of organizational governance. The more elements that are present and that have been implemented in respect of organizational governance, the more mature the organization would be. 


\subsection{The concept of Internal Audit}

Internal audit is a basic examination of working of different activities of a venture including the working of the arrangement of the interior check (Mustafa, Fatima, Saleem and Ul-Ain, 2016). As per Ziaee (2015), internal audit is an independent, target affirmation and counselling movement intended to include and enhance the firm's activities. It propels an organisation to achieve its goals by bringing a procedural and established principle to achieve organizational goal. Therefore, the Internal Audit Function (IAF) is the instrument through which the task of the quality administration framework is formally observed and guaranteed (George, Theofanis \& Konstantinos, 2015).

Internal audit quality is the capacity to find and report the anomalies or potentially breaks (Haxhiraj, 2015). It involves the instrument through which data about the viability of the quality framework is assembled by inspectors chose from inside the organization yet, who is autonomy of the zone, capacity or strategies being evaluated.

\subsection{Management Support and Internal Audit Activity}

Internal auditors have a cosy association with association's management in their everyday exercises. They require great help and recognition from their management to be more successful and to accomplish the audit targets. Management bolster has an expansive result on internal audit (IA) viability in organisations. For instance, Usang and Salim (2015) for their situation investigation of IA quality and adequacy on open part demonstrates that the segment of management bolster comprises of the reaction to an audit finding and the promise to a quality internal audit which has a critical impact on IA viability.

Farouk and Hassan (2014) in their study contend that the general acknowledgement and valuation for internal audit inside the organization is firmly needy upon the help they get from senior management. Internal audit effectively looks for management bolster with assets, pledge to advance and convey their additional esteem.

Enofe, Mgbame, Osa-Erhabor and Ehiorobo (2013) examined the role of internal audit ineffective management in the public sector at the local government level in Nigeria. From the review and analysis carried out with the aid of the Z-test, the result revealed that internal audit effectiveness ensures efficiency in the productivity of the management team.

However, Dawuda, Ataribanan and Joseph (2012) examined management support services and its effect on the performance of the internal audit unit in the public sector of Ghana Enterprises. The relevant data for the study were gathered from questionnaire duly administered to respondents in Ghana and from the analysis the study revealed that internal auditors were satisfied with the support services provided by management and advocated also for more commitment from management as a way of improving the effectiveness of the internal audit functions.

Besides, Usang and Salim, (2007) revealed that to recognize and anticipate extortion, misappropriation of assets and wastefulness in the corporate organisation in Nigeria, it is compulsory to have successful internal audit work that thus needs fitting management structure, activating adequate and proper asset and skilled staff. Hence, we hypothesise that: There is no significant relationship between management supports an internal audit activity in Nigeria.

\subsection{Management Perception of the Internal Audit Function and Internal Audit Activity}

To work successfully, internal auditors and the clients of review management ought to have a comparative comprehension of what makes interior examining esteem included action. The inability to achieve this comprehension could result in the observation that internal audit is basically an obstruction to accomplishing generation destinations. This can result in underutilized review benefits and overlooked review proposals which antagonistically impact the adequacy of internal audit (George et al. 2015).

Sawam and Alzeban (2013) carried a study on the role of internal auditing in the public sector in Saudi Arabia. Semi-structured interviews were employed to gathered the data for the study and the study revealed that institutional factors played a significant role in the failure of internal audit to develop in Saudi Arabia public sector and that there exists a perception that powerful government agencies fail to appreciate the value of internal audit as a mechanism to improve efficiency and probity within the sector.

suggested that governance and internal audit function is inseparable. Stating that the issue of internal audit effectiveness should be utmost to the management particularly when the service is outsourced.

On the hand, Obert and Munyunguma (2014) carried out a study on internal audit perception and their impact on the performance of the internal audit staff in Zimbabwe. To achieve this objective the study gathered relevant data from a questionnaire administered to managers, head of sectors, supervisors and clerical staff. The findings from the study revealed that there is a negative perception of the internal audit unit which was premised on auditors failure to meet expectation gap, bad reputation, staff quality, issue of independence and professional competence.

Owen (2000) suggested that the internal audit unit need not be viewed from a negative perspective only. Stating that emphasis should not be on what is achieved by this unit only but rather on societal values and expectations. Re-emphasizing the need for due acknowledgement of the internal audit recommendations by 
management. Hence, we hypothesise that: There is no significant relationship between management perceptions and internal audit activity in Nigeria.

\section{METHODS}

This study employed descriptive research design in evaluating the effect of governance maturity on internal audit activity in Nigeria. Primary data were gathered from duly administered questionnaire to management and audit staff of federal and state government parastatal and agencies in Benin City, Edo State. And the agencies duly selected for this study were the University of Benin, University of Benin Teaching Hospital, Edo State Ministries of Finance and Edo State Board of Internal Revenue all in Benin City, Edo State. In order to get an adequate response from the public sectors management and internal audit staff regarding the effect of governance maturity on internal audit activity in Nigeria, one hundred (100) questionnaires were dispatched randomly among selected respondents across the selected public institutions as the sample size of the study. Thereafter, the ordinary least square method statistically method was to analyse data.

\subsection{Data Collection Instrument}

The research instrument used was a questionnaire, in order words; the major source of data collection for the study was through primary data. The questionnaire was adopted and modified from the prior studies of Almatarneh (2011) and Shewamene (2014), an approach which is acceptable in methodological literature for studies of this nature as posited by Bryman and Bell (2007). The questionnaire was prepared in the form of five-point LikertScale type showing respondents' degree of agreement and or disagreement where the lowest scale represent strongly disagree and the highest scale represent strongly agree in line with Likert (1932). The questionnaire was organized into two parts; the first part comprises the demographic questions regarding the respondents, and the second part contains items relating to the internal audit quality and its determinants.

\subsection{Method of Data Analyses and Model Specification}

The data were analyzed through descriptive statistics in order to provide details regarding the demographic questions and the various factors that affect the activity of internal audit in the public sector. To evaluate the associations of the various factors on the quality of internal audit in the public sector, the correlation analysis was used. To predict and determine the relationship among the variables and to test the research hypotheses, the regression analysis method is used by meeting the ordinary least square (OLS) assumptions of the linear regression.

To this end, the following econometric model is formulated for this research in order to test the research hypotheses earlier stated under the review of literature:

IAA $=\beta_{0}+\beta_{1}$ MGTS $+\beta_{2}$ MGTP $+\varepsilon$

$\beta_{0}=$ coefficient of regression constants

$\beta_{1,2}$, = regression coefficient of each proxy

IAA $=$ Internal Audit Activity (dependent variable)

MGTS = Management Support

MGTP $=$ Management Perception

$\varepsilon=$ error term

*The variables in the study were obtained from the questionnaire

\subsection{Analysis of Result and Test Of Hypotheses}

Internal Audit Activity

Research Question 1: Internal Audit Quality ensures the protection of assets from errors and irregularities

TABLE 1.1: ANALYSIS OF QUESTION 1

\begin{tabular}{|l|l|}
\hline INTERNAL AUDIT ACTIVITY & PERCENTAGE (\%) \\
\hline UNDECIDED & 3 \\
\hline AGREE & 28 \\
\hline STRONGLY AGREE & 69 \\
\hline TOTAL & 100 \\
\hline
\end{tabular}

From the results contained in table 1.1 above, the percentage for Strongly Agree $(69 \%)$ and that of Agree $(28 \%)$ is higher than that of Undecided (3\%), this shows that the respondents are in congruence about the question put forth.

Research Question 2: Internal Audit Quality provides accurate comprehensive and temporariness in financial reporting. 
TABLE 1.2: ANALYSIS OF RESEARCH QUESTION 2

\begin{tabular}{|l|l|}
\hline INTERNAL AUDIT ACTIVITY & PERCENTAGE (\%) \\
\hline DISAGREE & 2 \\
\hline UNDECIDED & 11 \\
\hline AGREE & 64 \\
\hline STRONGLY AGREE & 23 \\
\hline TOTAL & 100 \\
\hline
\end{tabular}

From the results contained in Table 1.2 above, the percentage for Agree $(64 \%)$ and that of Strongly Agree $(23 \%)$ surpass that of Undecided(11\%) and Disagree(2\%) which depicts that the respondents are in congruence about the question put forth.

Research Question 3: The external auditor, the audit committee and management are provided with the necessary information through internal audit quality.

TABLE 1.3: ANALYSIS OF RESEARCH QUESTION 3

\begin{tabular}{|l|l|}
\hline INTERNAL AUDIT ACTIVITY & PERCENTAGE (\%) \\
\hline DISAGREE & 2 \\
\hline UNDECIDED & 22 \\
\hline AGREE & 34 \\
\hline STRONGLY AGREE & 42 \\
\hline TOTAL & 100 \\
\hline
\end{tabular}

The results contained in Table 1.3 above shows that the percentage for Strongly Agree (42\%) and that of Agree (34\%) are more than that of Undecided (22\%) and Disagree $(2 \%)$ which therefore displays that the respondents are in congruence about the question put forth.

Research Question 4: Internal auditors focus on performance audit and adopting the audit approach on the basis of audit risk.

TABLE 1.4: ANALYSIS OF RESEARCH QUESTION 4

\begin{tabular}{|l|l|}
\hline INTERNAL AUDIT ACTIVITY & PERCENTAGE (\%) \\
\hline DISAGREE & 2 \\
\hline UNDECIDED & 18 \\
\hline AGREE & 47 \\
\hline STRONGLY AGREE & 33 \\
\hline TOTAL & 100 \\
\hline
\end{tabular}

From the results contained in Table 1.4 above, the percentage for Strongly Agree(33\%) and Agree( $47 \%)$ are more than that of Disagree(2\%) and Undecided(18\%) which shows that the respondents are in congruence about the question put forth.

Research Question 5: The application of generally accepted accounting principles is a quality of an internal auditor.

TABLE 1.5: ANALYSIS OF RESEARCH QUESTION 5

\begin{tabular}{|l|l|}
\hline INTERNAL AUDIT ACTIVITY & PERCENTAGE(\%) \\
\hline STRONGLY DISAGREE & 1 \\
\hline DISAGREE & 1 \\
\hline UNDECIDED & 24 \\
\hline AGREE & 37 \\
\hline STRONGLY AGREE & 37 \\
\hline TOTAL & 100 \\
\hline
\end{tabular}

From the results contained in Table 1.5 above, the percentage for Strongly Agree(37\%) and Agree (37\%) are higher than that of Undecided(24\%),Disagree(1\%) and Strongly Disagree(1\%) which shows that the respondents are in congruence about the question put forth.

Research Question 6: Internal auditor owes it as a duty to assess the administrative performance and its plans to achieve the company goals.

TABLE 1.6: ANALYSIS OF RESEARCH QUESTION 6

\begin{tabular}{|l|l|}
\hline INTERNAL AUDIT ACTIVITY & PERCENTAGE(\%) \\
\hline STRONGLY DISAGREE & 3 \\
\hline DISAGREE & 5 \\
\hline UNDECIDED & 31 \\
\hline AGREE & 41 \\
\hline STRONGLY AGREE & 20 \\
\hline TOTAL & 100 \\
\hline
\end{tabular}

From the results contained in Table 1.6 above, the percentage for Agree( $41 \%)$ and that of Strongly Agree $(20 \%)$ 
are more than that of Undecided(31\%),Disagree(5\%) and Strongly Disagree(3\%) which shows that the respondents are in congruence about the question put forth.

Management Support

Research Question 7: Management Support facilitates access to records and information

TABLE 1.7: ANALYSIS OF RESEARCH QUESTION 7

\begin{tabular}{|l|l|}
\hline MANAGEMENT SUPPORT & PERCENTAGE(\%) \\
\hline DISAGREE & 1 \\
\hline UNDECIDED & 7 \\
\hline AGREE & 35 \\
\hline STRONGLY AGREE & 57 \\
\hline TOTAL & 100 \\
\hline
\end{tabular}

From the results contained in Table 1.7 above, the percentage for Strongly Agree (57\%) and that of Agree $(35 \%)$ are more than that of Undecided(7\%) and Disagree(1\%) which reveals that the respondents are in congruence about the question put forth.

Research Question 8: The necessary resources (facilities) that help in performing the requisite auditing activities can be derived through management support

TABLE 1.8: ANALYSIS OF RESEARCH QUESTION 8

\begin{tabular}{|l|l|}
\hline MANAGEMENT SUPPORT & PERCENTAGE(\%) \\
\hline STRONGLY DISAGREE & 1 \\
\hline DISAGREE & 4 \\
\hline UNDECIDED & 18 \\
\hline AGREE & 56 \\
\hline STRONGLY AGREE & 21 \\
\hline TOTAL & 100 \\
\hline
\end{tabular}

From the results contained in Table 1.8 above, the percentage for Agree(56\%) and that of Strongly Agree( $21 \%)$ are higher than that of Undecided(18\%),Disagree(4\%) and Strongly Disagree(1\%) which reveals that the respondents are in congruence about the question put forth.

Research Question 9: Management support brings about the training that helps in the improvement of skills and also helps in updating members of an organization with relevant information pertaining to the field

TABLE 1.9: ANALYSIS OF RESEARCH QUESTION 9

\begin{tabular}{|l|l|}
\hline MANAGEMENT SUPPORT & PERCENTAGE(\%) \\
\hline STRONGLY DISAGREE & 1 \\
\hline DISAGREE & 8 \\
\hline UNDECIDED & 18 \\
\hline AGREE & 41 \\
\hline STRONGLY AGREE & 32 \\
\hline TOTAL & 100 \\
\hline
\end{tabular}

From the results contained in Table 1.9, the percentage for Agree(41\%) and Strongly Agree(32\%) are more than that of Undecided(18\%), Disagree( $8 \%$ ) and Strongly Disagree(1\%) which reveals that the respondents are in congruence about the question put forth.

Research Question 10: Management support helps in keeping individuals of an organization abreast with new technologies, policies or procedures where necessary.

TABLE 1.10 ANALYSIS OF RESEARCH QUESTION 10

\begin{tabular}{|l|l|}
\hline MANAGEMENT SUPPORT & PERCENTAGE(\%) \\
\hline STRONGLY DISAGREE & 2 \\
\hline DISAGREE & 1 \\
\hline UNDECIDED & 29 \\
\hline AGREE & 38 \\
\hline STRONGLY AGREE & 30 \\
\hline TOTAL & 100 \\
\hline
\end{tabular}

From the results contained in Table 1.10, the percentage for Agree(38\%) and that of Strongly Agree(30\%) are more than that of Undecided(29\%),Disagree(1\%) and Strongly Disagree(2\%) which therefore reveals that the respondents are in congruence about the question put forth.

Research Question 11: Management support helps internal auditing staff by budgeting funds for certification to have relevant education in auditing and also facilitates a sound audit of all organization. 
TABLE 1.11 ANALYSIS OF RESEARCH QUESTION 11

\begin{tabular}{|l|l|}
\hline MANAGEMENT SUPPORT & PERCENTAGE $(\%)$ \\
\hline STRONGLY DISAGREE & 2 \\
\hline DISAGREE & 3 \\
\hline UNDECIDED & 21 \\
\hline AGREE & 37 \\
\hline STRONGLY AGREE & 37 \\
\hline TOTAL & 100 \\
\hline
\end{tabular}

From the results contained in Table 1.11 above, the percentage for Agree(37\%) and that of Disagree(37\%) are more than that of Undecided (21\%),Disagree(3\%) and Strongly Disagree(2\%) which therefore shows that the respondents are in congruence about the question put forth.

Management's Perception Of Internal Audit Function

Research Question 12: Management's perception of the internal audit function enables an organization to be aware of internal auditing roles.

TABLE 1.12 ANALYSIS OF RESEARCH QUESTION 12

\begin{tabular}{|l|l|}
\hline $\begin{array}{l}\text { MANAGEMENT'S PERCEPTION OF } \\
\text { INTERNAL AUDIT FUNCTION }\end{array}$ & PERCENTAGE(\%) \\
\hline STRONGLY DISAGREE & 1 \\
\hline DISAGREE & 5 \\
\hline UNDECIDED & 12 \\
\hline AGREE & 49 \\
\hline STRONGLY AGREE & 33 \\
\hline TOTAL & 100 \\
\hline
\end{tabular}

From the results contained in Table 1.12,the percentage for Agree $(49 \%)$ and that of Strongly Agree $(33 \%)$ are higher than that of Undecided(12\%),Disagree(5\%) and Strongly Agree(1\%) which reveals that the respondents are in congruence about the question put forth.

Research Question 13: The Organization considers internal auditing practices as a value-adding activity and this helps individuals in an organization to work smoothly and regularly with the management through management's perception of the internal audit function.

TABLE 1.13 ANALYSIS OF RESEARCH QUESTION 13

\begin{tabular}{|l|l|}
\hline $\begin{array}{l}\text { MANAGEMENT'S PERCEPTION OF } \\
\text { INTERNAL AUDIT FUNCTION }\end{array}$ & PERCENTAGE(\%) \\
\hline STRONGLY DISAGREE & 1 \\
\hline DISAGREE & 9 \\
\hline UNDECIDED & 29 \\
\hline AGREE & 47 \\
\hline STRONGLY AGREE & 14 \\
\hline TOTAL & 100 \\
\hline
\end{tabular}

From the results contained in Table 1.13,the percentage for Agree $(47 \%)$ and that of Strongly Agree(14\%) are more higher than that of Undecided(29\%),Disagree(9\%) and Strongly Disagree(1\%) which shows that the respondents are in congruence about the question put forth.

Research Question 14: The organization encourages its members to implement recommendations, provide-value added activities and to strengthen the internal audit function.

TABLE 1.14 ANALYSIS OF RESEARCH QUESTION 14

\begin{tabular}{|l|l|}
\hline $\begin{array}{l}\text { MANAGEMENT'S PERCEPTION OF } \\
\text { INTERNAL AUDIT FUNCTION }\end{array}$ & PERCENTAGE(\%) \\
\hline STRONGLY DISAGREE & 2 \\
\hline DISAGREE & 5 \\
\hline UNDECIDED & 19 \\
\hline AGREE & 42 \\
\hline STRONGLY AGREE & 32 \\
\hline TOTAL & 100 \\
\hline
\end{tabular}

From the results contained in Table 1.14,the percentage for Agree(42\%) and that of Strongly Agree(32\%) are more higher than that of Undecided(19\%),Disagree(5\%) and Strongly Disagree(2\%) which shows that the respondents are in congruence about the question put forth.

Research Question 15: The position/status of internal audit is clearly recognized by the management in any organization. 
TABLE 1.15 ANALYSIS OF RESEARCH QUESTION 15

\begin{tabular}{|l|l|}
\hline MANAGEMENT'S PERCEPTION OF INTERNAL AUDIT FUNCTION & PERCENTAGE(\%) \\
\hline STRONGLY DISAGREE & 3 \\
\hline DISAGREE & 3 \\
\hline UNDECIDED & 27 \\
\hline AGREE & 43 \\
\hline STRONGLY AGREE & 24 \\
\hline TOTAL & 100 \\
\hline
\end{tabular}

From the results contained in Table 1.15,the percentage for Agree (43\%) and that of Strongly Agree( $24 \%)$ are more higher than that of Undecided(27\%),Disagree(3\%) and Strongly Disagree(3\%) which shows that the respondents are in congruence about the question put forth.

Research Question 16: Through management's perception of the internal audit function, the organization sees internal auditing as providing internal assurance through investigations, checks, assessments, consulting and advisory services pertaining to controls associated with management performance and internal operations.

TABLE 1.16 ANALYSIS OF RESEARCH QUESTION 16

\begin{tabular}{|l|l|}
\hline MANAGEMENT'S PERCEPTION OF INTERNAL AUDIT FUNCTION & PERCENTAGE(\%) \\
\hline STRONGLY DISAGREE & 1 \\
\hline DISAGREE & 1 \\
\hline UNDECIDED & 7 \\
\hline AGREE & 27 \\
\hline STRONGLY AGREE & 64 \\
\hline TOTAL & 100 \\
\hline
\end{tabular}

From the results contained in Table 1.16, the percentage for Strongly Agree $(64 \%)$ and that of Agree (27\%)are more higher than that of Undecided(7\%),Disagree(1\%) and Strongly Disagree(1\%) which shows that the respondents are in congruence about the question put forth.

Ordinary Least Squares Result

Table 2 Ordinary Least Squares

Dependent Variable: IAA

Method: Least Squares

Date: 01/27/19 Time: 17:29

Sample: 1100

Included observations: 100

\begin{tabular}{lrlrr}
\hline \hline \multicolumn{1}{c}{ Variable } & Coefficient & Std. Error & t-Statistic & Prob. \\
\hline \hline \multicolumn{1}{c}{ MPIAF } & -0.077232 & 0.097231 & -0.794322 & 0.4289 \\
MS & 0.135610 & 0.096699 & 1.402399 & 0.1640 \\
\multicolumn{1}{c}{} & 3.889940 & 0.403494 & 9.640651 & 0.0000 \\
\hline \hline R-squared & 0.020086 & Mean dependent var & & 4.131667 \\
Adjusted R-squared & -0.000118 & S.D. dependent var & & 0.426596 \\
S.E. of regression & 0.426621 & Akaike info criterion & & 1.163698 \\
Sum squared resid & 17.65451 & Schwarz criterion & & 1.241853 \\
Log-likelihood & -55.18490 & Hannan-Quinn criter. & & 1.195329 \\
F-statistic & 0.994151 & Durbin-Watson stat & & 1.646540 \\
Prob(F-statistic) & 0.373776 & & \\
\hline
\end{tabular}

\section{Source: Researchers Computations (2019)}

The regression result is presented in Table 2. The R-squared value of 0.020086 indicates that about $2 \%$ systematic cross-sectional variation in internal audit activity is accounted for by the independent variables of management support and management perception. The robust F-statistic of 0.994151 and the associated probability value of 0.373776 indicates an insignificant linear relationship between the dependent variable and the explanatory variables. The Durbin-Watson statistic of 1.646540 is not substantially different from the 2.00 benchmark and indicative of the absence of the problem of multicollinearity.

Management support reported a positive coefficient of 0.135610 and a robust t-value of 1.402399 which means that management support has an insignificant association with internal audit activity. This implies that a 1 percentage change management support will lead to about 13 percentage increase in internal audit activity.

Management perception reported a negative coefficient of -0.077232 and a robust t-value of -0.794322 and by 
implication have an insignificant association with internal audit activity. This implies that a 1 percentage change management perception will lead to about 7 percentage decrease in internal audit activity.

Table 3: Results of the Variance Inflation Factor

\begin{tabular}{cccc}
\hline \hline & Coefficient & Uncentered & Centered \\
Variable & Variance & VIF & 1.290060 \\
VIF & & 84.64730 & 1.290060 \\
MS & 0.009454 & 86.14240 & NA \\
C & 0.009351 & 89.45184 & \\
\hline \hline
\end{tabular}

Source: Researchers Computation (2019)

The result of the variance inflation factor in Table 3 further strengthens the result of the correlation coefficient. The centred variance inflation factor of the variables are not substantially different from 1.00 and below the benchmark of 10, above which is an indication of the problem of multicollinearity.

Table 4: Results of the Regression Diagnostics

\begin{tabular}{|l|l|l|l|}
\hline Diagnostic Test & Test type & $\begin{array}{l}\text { F-Value } \\
\text { (probability) }\end{array}$ & Remarks \\
\hline Serial correlation & Breusch- Godfrey & $2.383232(0.0977)$ & Not serially correlated \\
\hline Heteroskedasticity & Breusch-Pagan-Godfrey & $2.169637(0.1197)$ & Homoskedasticity \\
\hline
\end{tabular}

\section{Source: Researchers Computations (2019}

The results of the classical regression assumption tests are presented in Table 4. The result of the serial correlation test using the Breusch-Godfrey test reported a probability value of 0.0977 and F-statistic of 2.383232. The result is insignificant and could not sustain the null hypothesis of seriality correlated variables, and the alternate hypothesis of the absence of serial correlation was accepted. The null hypothesis of heteroskedastic residuals was rejected based on the insignificant value of the probability of 0.1197 . The alternate hypothesis of homoskedastic residuals was accepted.

\subsection{Discussion of Findings}

The earlier stated hypotheses were tested based on the result obtained from the ordinary least square (table 2). The study sets its decision rule for the acceptance of the hypothesis at 5\% level of significance; hence, the hypothesis would be accepted if the probability is less than 0.05 .

From the result in table 2, management support shows a positive effect on internal audit activity. The ordinary least square analysis (table 2), management support with a t-value of 1.402399 and a p-value of 0.1640 had an insignificant relationship with internal audit activity. We, therefore, accept the null hypothesis and reject the alternative, which states that management support has no significant relationship with internal audit activity. This study corroborates the study of Usang and Salim, (2007).

However, management perception exhibited a negative relationship with internal audit activity. The ordinary least square result as shown in table 2 shows that nationality diversity with a t-value of -0.077232 probability value of 0.4289 had an insignificant relationship with internal audit activity. The paper, therefore, accepts the null hypothesis which says that management perception has no significant relationship with internal audit activity and rejects the alternative. This study is therefore in consonance with the study of Obert and Munyunguma (2014).

\section{Conclusion and Recommendations}

This paper evaluated the effect of management support and perception of the internal audit function in public establishment in Benin City, Edo State. From the review of literature and analysis of data gathered the paper concluded that management support and management perception have no significant effect on internal audit activities in public establishments. Premised on the conclusion the paper recommended that there is a need for robust management support to enhance efficiency and effectiveness of the internal audit unit and also that management perception of the audit is pivotal in other for them to achieve set objective and other organizational goals.

\section{References}

Adigwe, P. K., Nwanna, I. O. \& John, E. I. (2016). Effect of corporate governance mechanism on the financial performance of banks in Nigeria. NG-Journal of Social Development, 5(2), $41-50$.

Ahsan, A. (2015). The role of corporate governance mechanism in optimizing firm performance: a conceptual model for corporate sector of Pakistan, Journal of Asian Business strategy, 5(6), 109-115

Atu, O.G., Adeghe, R. \& Atu, O.O.K. (2014). Internal control as a potential instrument for corporate governance, Journal of Economics and Finance, 2(6), 66-70 
Bryman, A. \& Bell. E. (2007). Business research methods. Oxford university press, USA

Cohen, A. \& Sayag, G. (2010). The effectiveness of internal auditing: an empirical examination of its determinants in Israeli organizations, Austr. Account. Rev. 20(3), 296-307

Dawuda, A., Ataribanan, S., \& Joseph, A.A. (2012). An exploratory study on management support services and its effects on the quality service delivering of internal auditors in northern Ghana. International Journal of Accounting Research. 5 (2), 12-19

Deribe, J.W.\& Regasa, G.D. (2014). Factors determining internal audit quality: empirical evidence from Ethiopian commercial banks, Research Journal of Finance and Accounting, 5(23),01-10

Duke, J. \& Kankpang, K. (2011). Linking corporate governance with organizational performance: new insights and evidence from Nigeria, Global Journal of Management and Business Research, 11(12), 47-57

Ebrahim, M.A., Abdullah, K.A. \& Faudziah, H.B.F. (2014). The effect of the internal audit on firm performance: a proposed research framework, International Review of Management and Marketing, 4(1), 34-41

Ejoh, N.O. \& Ejom, P.E. (2014). The effect of internal audit function on the financial performance of tertiary institutions in Nigeria, International Journal of Economics, Commerce and Management, 11(10), 1-14

Enofe, A.O., Mgbame, C.J., Osa-Erhabor, V.E. \& Ehiorobo, A.J. (2013). The role of internal audit in effective management in public sector. Research Journal of Finance and Accounting. 4(6), 162-168

Farouk, A. M. \& Hassan, U.S. (2014). Impact of audit quality and financial performance of quoted cement firms in Nigeria. International Journal of Accounting and Taxation, American, 2(2), 01-22

George, D., Theofanis, K. \& Konstantinos, A. (2015). Factors associated with Internal Audit Effectiveness: Evidence from Greece. Journal of Accounting and Taxation, 7(7), 113-122.

Gramling, A. A. \& Hermanson, D. R. (2006), What role is your internal audit function playing in corporate governance? Internal Auditing, 21(6), 37 - 39.

Haxhiraj, E. (2015). The perceptions on IIA'S standards and internal audit quality: evidence from Albania Banking Industry. Mediterranean Journal of Social Sciences, 6(1), 147-155.

Khatab, H., Masood, M., Zaman, K., Saleem, S. \& Saeed, B. (2011). Corporate governance and firm performance: a case study of Karachi stock market, International Journal of Trade, Economics and Finance, 2(1), 39-43

Magdi, R. \& Nadareh. R. (2002). Corporate governance: a framework for implementation. Britain World Group Journal, 20, 123-132

Marks, N. (2007), Internal Audits of Governance, Internal Auditor, 64(6), 31 - 32.

Mustafa, G., Fatima, S., Saleem, S. \& Ul-Ain, N. (2016). An empirical study of internal audit and firm performance: A proposed research framework. International Journal of Information Research and Review, 3(3), 1952-1956.

Obert, S. \& Munyunguna, I.N.(2014). Internal audit perceptions and their impact on performance of the internal audit function. IOSR Journal of Business and Management. 16(5), 81-85

Philna, C. \& Houdini, F. (2010). Perception on the role of the internal audit function in respect of risk. Africa Journal of Business Management. 3(13), 959-968

Ponduri, S. B., Sailaja, V. \& Begum, S. A. (2014). Corporate governance - emerging economies fraud and fraud prevention. IOSR Journal of Business and Management, 16(3), $1-7$.

Salihu, A. M. (2015). An assessment of the effectiveness of internal audit unit at local government level in Adamawa State, International Journal of Humanities and Social Science, 5(4), 59-65

Usang, E.U.O. \& Salim, B. (2015). A conceptual perspective of internal audit quality and local government performance in Nigeria. Presented at Malaysia International Conference on Accounting Studies

Wilkinson, N. \& Plant, K. (2012), A framework for the development of an organizational governance maturity model: a tool for internal auditors. Southern African Journal of Accountability and Auditing Research, 13(1), 19-31.

Ziaee, M. (2015). The effect of audit quality on the performance of listed companies in Tehran Stock Exchange. International Letters of Social and Humanistic Sciences, 21(1), 36 - 43.

1. Sex: Male [ ] Female [ ]

\section{SECTION A: Socio-demographic Characteristics}

2. Age: Below 30yrs [ ] 31-40years [ ] $41-50$ years [ ] 51years and 60 years [ ] Above 60 years

3. Educational Qualification: SSCE [ ] OND/Diploma [ ] B.Sc/HND[ ] MBA/M.Sc [ ] Others [ ]

4. Professionalism: ICAN [ ], ANAN [ ], ACCA [ ]

5. Field of Study: Accounting [ ] Management [ ] Economics [ ], Others.

6. Work experience: 5 to 10 years [ ] 11 to 15 years [ ] 16 to 20 years [ ] Above 20 years.

\section{SECTION B}

Please read and tick $[\sqrt{ }]$ the column that best describes your response using the guide as shown below:

SA

A
$=$ Strongly Agree (5 points)

$=$ Agree (4 points) 


\begin{tabular}{|c|c|c|c|c|c|c|}
\hline $\begin{array}{l}\text { UD } \\
\text { D } \\
\text { SD }\end{array}$ & $\begin{array}{l}=\text { Undecided }(3 \text { points }) \\
=\text { Disagree }(2 \text { points }) \\
=\text { Strongly Disagree }(1 \text { point })\end{array}$ & & & & & \\
\hline $\mathbf{S} / \mathbf{N}$ & Internal Audit Activity & SA & $\mathbf{A}$ & UD & $\mathbf{D}$ & SD \\
\hline 1 & $\begin{array}{l}\text { Internal audit quality ensures the protection of the assets from errors and } \\
\text { irregularities. }\end{array}$ & & & & & \\
\hline 2 & $\begin{array}{l}\text { Internal audit quality provides accurate comprehensive and temporariness } \\
\text { in financial reporting. }\end{array}$ & & & & & \\
\hline 3 & $\begin{array}{l}\text { The external auditor, the audit committee and management are provided } \\
\text { with the necessary information through internal audit quality. }\end{array}$ & & & & & \\
\hline 4 & $\begin{array}{l}\text { Internal auditors focus on performance audit and adopting the audit } \\
\text { approach on the basis of audit risk. }\end{array}$ & & & & & \\
\hline 5 & $\begin{array}{l}\text { The application of generally accepted accounting principles is a quality of } \\
\text { internal auditor }\end{array}$ & & & & & \\
\hline 6 & $\begin{array}{l}\text { Internal auditor owes it as a duty to assess the administrative performance } \\
\text { and its plans to achieve the company goals. }\end{array}$ & & & & & \\
\hline $\mathbf{S} / \mathbf{N}$ & Management Support & SA & $\mathbf{A}$ & UD & $\mathbf{D}$ & SD \\
\hline 7 & Management support facilitates access to records and information & & & & & \\
\hline 8 & $\begin{array}{l}\text { The necessary resources (facilities) that help in performing the requisite } \\
\text { auditing activities can be derived through management support }\end{array}$ & & & & & \\
\hline 9 & $\begin{array}{l}\text { Management support brings about the training that helps in the } \\
\text { improvement of skills and also helps in updating members of an } \\
\text { organization with relevant information pertaining to the field }\end{array}$ & & & & & \\
\hline 10 & $\begin{array}{l}\text { Management support helps in keeping individuals of an organization } \\
\text { abreast with new technologies, policies or procedures where necessary }\end{array}$ & & & & & \\
\hline \multirow[t]{2}{*}{11} & $\begin{array}{l}\text { Management support helps internal auditing staff by budgeting funds for } \\
\text { certification to have relevant education in auditing and also facilitates a } \\
\text { sound audit of all organization }\end{array}$ & & & & & \\
\hline & Management's perception of the internal audit function & SA & $\mathbf{A}$ & UD & $\mathbf{D}$ & SD \\
\hline 12 & $\begin{array}{l}\text { Management perception of the internal audit function enables an } \\
\text { organization to be aware of internal auditing roles }\end{array}$ & & & & & \\
\hline 13 & $\begin{array}{l}\text { The organization considers internal auditing practices as a value-adding } \\
\text { activity and this helps individuals in an organization to work smoothly and } \\
\text { regularly with the management through management's perception of the } \\
\text { internal audit function }\end{array}$ & & & & & \\
\hline 14 & $\begin{array}{l}\text { The organization encourages its members to implement recommendations, } \\
\text { provide-value added activities and to strengthen the internal audit function }\end{array}$ & & & & & \\
\hline 15 & $\begin{array}{l}\text { The position/status of internal audit is clearly recognized by the } \\
\text { management in any organization }\end{array}$ & & & & & \\
\hline 16 & $\begin{array}{l}\text { Through management's perception of the internal audit function, the } \\
\text { organization sees internal auditing as providing internal assurance through } \\
\text { investigations, checks, assessments, consulting and advisory services } \\
\text { pertaining to controls associated with management performance and } \\
\text { internal operations }\end{array}$ & & & & & \\
\hline
\end{tabular}

